\title{
Immunohistochemical study on the epithelial component of Warthin's tumor
}

\author{
Hiroshi Takahashi, Nobuo Tsuda* and Haruo Okabe \\ Department of Oral Pathology, Nagasaki University School of Dentistry, \\ *Pathology Division, Central Diagnostic Laboratory, Nagasaki University Hospital, \\ 7-1 Sakamoto-machi, Nagasaki 852, Japan
}

[Accepted for publication: September 20, 1984]

Key words: Warthin's tumor/oncocyte/immunohistochemical study/immunoglobulin / carcinoembryonic antigen

\begin{abstract}
The epithelial components of 10 Warthin's tumors (adenolymphomas) were studied by immunohistochemical technique. The neoplastic epithelium consisted of tall columnar apical cells and irregularly shaped basal cells. IgA was predominant in the columnar cells and in the intraluminal secretion of the tumor. IgG-containing cells were scattered in 8 of 10 cases, but no IgM was detected. Carcinoembryonic antigen (CEA), normally absent from striated ducts, was found in small groups of neoplastic columnar cells.

Warthin's tumor, therefore, seems to be composed of neoplastic duct epithelium, most of which is highly differentiated with retention of immunoglobulin transport and appearance of CEA. Immunoglobulins and CEA were found in the tall columnar cells, but they were almost negative in the basal cells. It was suggested that the tall columnar epithelial cells of Warthin's tumor were different from basal cells in point of their functional state.
\end{abstract}

\section{Introduction}

Papillary cystadenoma lymphomatosum, better known as Warthin's tumor, was first described in 1910 by Albrecht and Arzt ${ }^{11}$ and further characterized by Warthin ${ }^{2}$ in 1929. Later, numerous reports on the clinicopathological features and histogenesis of this tumor have appeared. It has been suggested that the tumor forms as a result of the neoplastic transformation of the paroid ducts that have been entrapped in lymph nodes during development ${ }^{3)}$. In 1971, Warthin's tumor was suggested to be a tissue reaction of the delayed hypersensitivity type triggered by oxyphilic metaplasia of the ductal epithelium of the parotid gland ${ }^{4}$. After that, Warthin's tumor was classified as an adenolymphoma, a subtype of the salivary gland monomorphic adenoma ${ }^{5}$. Thus, ductal epithelium seems to play an important role in the formation of the tumor. Little attention has, however, been given to immunological characteristics in the epithelial component of Warthin's tumor.

The purpose of the present study was to examine the presence and distribution of the immunoglobulins and CEA in the epithelial component composed of two oxyphilic layers of cells similar to oncocytes.

\section{Materials and Methods}

Surgical specimens consisted of 10 Warthin's tumors from the files of the Pathology Division, Central Diagnostic Laboratory, Nagasaki University Hospital. The tissue was fixed in $10 \%$ formalin, embedded in paraffin, and stained with hematoxylin and eosin $(\mathbf{H}$ \& E), periodic acid-Schiff reagent (PAS) and alcian-blue.

Representative formalin fixed paraffin embedded sections were immuno-stained using the peroxidase anti-peroxidase (PAP) technique of Sternberger $(1979)^{\text {B) }}$. Primary antiserum produced in rabbits specifically directed against Ig A, IgG, IgM and CEA was 
obtained from DAKO (Copenhagen, Denmark). Anti-CEA serum was absorbed with tissue powder from normal human spleen before use to remove non-specific crossreacting antigen (NCA). The tissue powder was prepared by the method described by von Kleist $(1972)^{7}$. Following incubation in a $3 \%$ hydrogen peroxide solution to consume endogenous peroxidase activity, the slides were incubated sequentially with primary antiserum, swine anti-rabbit serum protein, and horseradish peroxidase rabbit antihorseradish peroxidase soluble complexes (DAKO). Antibody localization was affected with a fresh solution of 3-amino-9-ethylcarbazole (AEC) containing N,N-dimethyl formamide, giving a brown reaction product. Through washing in phosphate buffered saline $\mathrm{pH} 7.4$ (PBS) was carried out between each step. The sections were counterstained with hematoxylin. Control sections of the tonsil revealed strong staining for $\operatorname{IgA}$, $\operatorname{IgG}$ and $\operatorname{IgM}$ and sections of colon carcinoma stained for CEA. Specificity of the reactions was tested as follows: 1) non-immune rabbit serum was used as the first step, 2) phosphatebuffered saline as the second step and 3 ) omission of AEC or $\mathrm{H}_{2} \mathrm{O}_{2}$ from the incubation medium for the peroxidase reaction.

Immunoglobulin and CEA immunoreactivities in the tumor tissue were graded $(-)$, $(+),(H)$ and (H) on the basis of the frequency of positive staining of tumor cells rather than the intensity of staining of individual cells.

\section{Results}

\section{Clinical findings}

The age, sex and site of 10 cases with Warthin's tumor are listed in Table 1 . The mean age was 61.2 years (range: $51-72$ ) and the male to female ratio $4: 1$. Eight of the lesions were in the parotid gland with only two examples found in the submandibular gland.

\section{Macro- and microscopic findings}

The histologic features of the neoplasms were similar to those already documented ${ }^{3,5}$. There was some variation in the sizes of the neoplasms, ranging from 1.5 to $3 \mathrm{~cm}$ in diameter.

The epithelial component of neoplasms was embedded in the lymphoid tissue with formation of tubular and cystic spaces, some of which contained secretion material. The cystic and tubular structures and the papillary fronds that projected into cystic cavities were lined by a two cell layered epithelium. In the epithelium of the tumor, tall columnar cells occurred at the apical portion and small irregularly shaped cells were found at the basal region. The papillary fronds varied in their size and the stroma was occupied by varying populations of plasma cells and other mononuclear cells.

3. Immunohistochemical study

Table 2 summarizes the immunoglobulins

Table 1 Clinical features of patients with Warthin's tumor.

\begin{tabular}{rccl}
\hline Case & $\begin{array}{c}\text { Year of } \\
\text { diagnosis }\end{array}$ & Age/Sex & \multicolumn{1}{c}{ Site } \\
\hline 1 & 1966 & $58 \mathrm{M}$ & Parotid gland, right \\
2 & 1968 & $63 \mathrm{M}$ & Submandibular gland, left \\
3 & 1973 & $72 \mathrm{M}$ & Parotid gland, right \\
4 & 1973 & $61 \mathrm{~F}$ & Parotid gland, right \\
5 & 1975 & $68 \mathrm{M}$ & Parotid gland, right \\
6 & 1975 & $51 \mathrm{M}$ & Parotid gland, left \\
7 & 1977 & $68 \mathrm{M}$ & Parotid gland, left \\
8 & 1977 & $56 \mathrm{~F}$ & Parotid gland, right \\
9 & 1982 & $62 \mathrm{M}$ & Submandibular gland, left \\
10 & 1982 & $53 \mathrm{M}$ & Parotid gland, right \\
\hline
\end{tabular}


Table 2 Grading of immunoglobulin and CEA immunoreactivities in tumor cells of 10 cases of Warthin's tumor.

\begin{tabular}{|c|c|c|c|c|}
\hline \multirow{3}{*}{$\begin{array}{l}\text { Grading of } \\
\text { immunoreactivity }\end{array}$} & \multicolumn{4}{|c|}{ Staining } \\
\hline & \multicolumn{3}{|c|}{ Immunoglobulin } & \multirow{2}{*}{ CEA } \\
\hline & $\operatorname{IgA}$ & IgG & IgM & \\
\hline- & 0 & 3 & 10 & 3 \\
\hline+ & 0 & 7 & 0 & 7 \\
\hline H & 4 & 0 & 0 & 0 \\
\hline 世 & 6 & 0 & 0 & 0 \\
\hline
\end{tabular}

* Tissue with more than $50 \%$ of the tumor cells having immunoreactivity was graded (両), 20 to $50 \%$ (H), less than $20 \%(+)$, and negative $(-)$.

and CEA immunoreactivities in tumor cells of 10 cases of Warthin's tumor. .

The epithelial component of Warthin's tumor was stained prominently for IgA in the cytoplasm of columnar cells (Fig. 1). The positivity for IgA was graded $(H)$ in four $(40 \%)$, and graded (H) in six $(60 \%)$. The cystic contents were also intensively positive for IgA. IgG immunoreactivity in tumor cells was observed as the minimal staining in 7 cases $(70 \%)$ and graded $(+)$, and the staining intensity was consistently weaker than that for IgA, however, no staining for IgM was seen.

CEA was observed in 7 cases $(70 \%)$ of Warthin's tumor and the positivity was graded $(+)$. As far as the localization of CEA in the neoplastic tissue is concerned, this antigen was clearly localized in intracellular area of columnar cells in the ductal, papillary and cystic fashions (Fig. 2). Positively stained material was also seen in the duct lumens and cystic spaces. But reaction product for CEA couldn't be observed in solid areas of tumor cells.

\section{Discussion}

Warthin's tumor of the salivary glands as observed in this study consists of epithelial component and lymphoid stroma. As has been described previously3), the epithelial component that forms ducts and lines cysitc
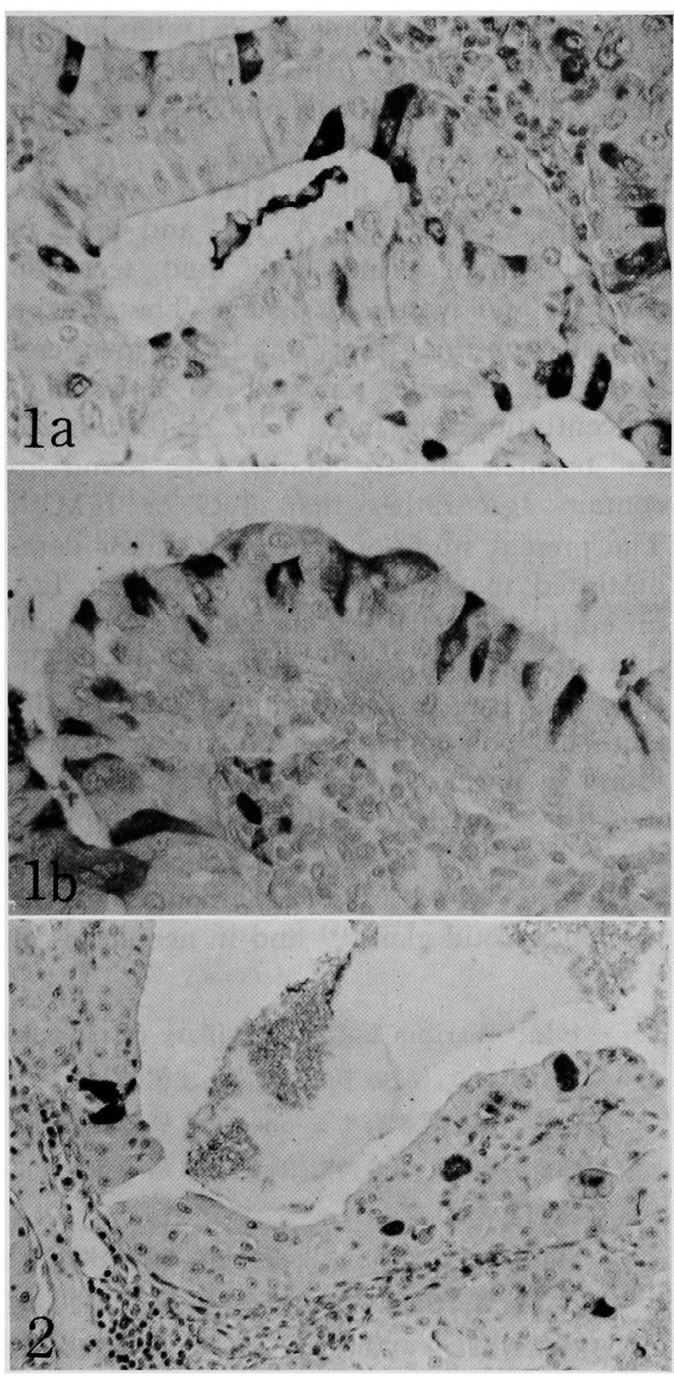

Fig. 1 Immunohistochemical staining for IgA in Warthin's tumor. Many of tumor cells in tubular (1a) and papillary (1b) structures, as well as intraluminal secretion, are stained (PAP, × 130).

Fig. 2 Immunohistochemical staining for CEA in Warthin's tumor. Some of tumor cells show CEA immunoreactivity (PAP, $\times 70)$.

spaces is made up of columnar apical cells and irregularly shaped basal cells. The cells of the neoplastic epithelium are morphologically similar to the oncocytes that are found in oncocytoma of the salivary gland ${ }^{8-10)}$ and normal salivary glands ${ }^{11}$. In this study, we 
employed immunohistochemical stainings to examine the cellular expression of $\operatorname{IgA}, \mathrm{IgG}$, IgM and CEA in the epithelial component of Warthin's tumor.

There are three main types of immunoglobulins, designated IgA, IgG and IgM, in normal human serum, body fluid, secretion material and lymphoid tissues. The mucosa of gastrointestinal tract ${ }^{12)}$ and exocrine secretion $^{13)}$ have been reported to show high concentrations of IgA. The epithelium of the normal salivary gland was found to contain IgA rather than IgG or $\operatorname{IgM}^{14)}$. The present study of Warthin's tumor demonstrated that the staining density for IgA in epithelial cells was much greater than that for IgG and IgM. Moreover, the localization of $\operatorname{IgA}$ in the columnar cells of the epithelial component is comparable to that found in normal salivary duct cells, suggesting a ductal origin of the neoplastic epithelium.

CEA is found in small amounts in the normal parotid gland ${ }^{15)}$ and in neoplasms of the parotid gland ${ }^{16)}$. However, there are few reports about the localization of CEA in Warthin's tumor. Our findings indicated that material identified immunohistochemically as CEA was present in $70 \%$ of cases of Warthin's tumor. CEA was localized in the cytoplasm of tall columnar cells forming glandular, papillary and cystic structures within this tumor. CEA could not be found in solid groups of neoplastic cells. The appearance of CEA was dependent on whether the glandular structures was well formed or not.

IgA and CEA were not detected in the basal cells of the Warthin's tumor. It was very interesting to note that there was a different staining pattern for IgA and CEA between columnar cells and basal cells in this tumor tissue. Therefore, concomitant use of the two immunohistochemical stains may offer a way to study the functional condition of epithelial cells of Warthin's tumor.

抄録: Warthin 腫瘍は, Papillary cystadenoma lymphomatosum 或いは Adenolymphoma などと呼 称されており, 組織学的には, 上皮組織とリンパ組織から構成され特徵的な像を呈している。上皮成分は 好酸性の細胞質を有する oncocyte 様の腫瘍細胞の増殖から成るが, 腺腔側の高円柱状細胞と基底側にお ける立方形ないし多角形細胞とが 2 層〜多層性に配列して, 腺管の形成や乳頭状・糞胞状および充実性の 様式をとっている。

Oncocyte に類似した 2 種の腫瘍細胞の性状を検討するために, 10 例の Warthin 腫瘍を用いて, IgA, IgG, IgM, CEA の分布を免疫組織化学的に検索した。尚, 染色度は次のように, (一): 陰性, $(+)$ : 陽性細胞が全体の $20 \%$ 以下，(H)：陽性細胞が 20〜50\%，(卅）：陽性細胞が $50 \%$ 以上，とした。IgA は 全例が陽性で (H)〜 (卅), IgG は7/10 が陽性で（十，IgM は全例陰性であった。また, CEA は7/10 が陽性，(十) であり，充実性の増殖巣を除く腫瘍組織内に散在性に認められた。これら免疫染色の陽性細 胞の全ては腺腔側の高円柱状細胞であり, 基底側の腫瘍細胞は陰性であった。以上のように, 正常唾液腺 組織に存在する IgA と CEA が, 本腫瘍の主として腺管形成性の部位に認められたこと, および腺腔側 の高円柱状細胞にだけ観察されたことの 2 点から，Warthin 腫瘍における IgA と CEA の存在は腫瘍 細胞の成熟度・分化度を表現しているものとみなされた。

\section{References}

1) Albrecht, H. and Arzt, L.: Beiträge zur Frage der Gewebsverirrung. Papilläre Cystadenome in Lymphdrüsen. Frankfurt $Z$. Path. 4: 47-69, 1910.

2) Warthin, A. S.: Papillary cystadenoma lymphomatosum; A rare teratoid of the parotid region. J. Cancer Res. 13: 116-125, 1929.

3) Thompson, A. S. and Bryant, H. C. Jr.: Histogenesis of papillary cystadenoma lymphomatosum (Warthin's tumor) of the parotid salivary gland. Am. J. Pathol. 26: 807849, 1950.

4) Allegra, S. R.: Warthin's tumor: A hypersensitivity disease? Ultrastructural, light and immunofluorescent study. Hum. Pathol. 2: 
403-420, 1971.

5) Thackray, A. C. and Lucas, R. B.: Tumors of the major salivary glands. Atlas of Tumor Pathology, Series II, Fascicle 10. Washington: Armed Forces Institute of Pathology, 1974.

6) Sternberger, L. A.: Immunocytochemistry. 2nd ed., John Wiley, New York, 1979.

7) von Kleist, S., Chavanel, G. and Burtin, P.: Identification of a normal antigen from normal human tissue that crossreacts with the carcinoembryonic antigen. Proc. Natl. Acad. Sci. USA 69: 2492-2494, 1972.

8) Balogh, K. Jr. and Roth, S. I.: Histochemical and electron microscopical studies of eosinophilic granular cells (oncocytes) in tumors of the parotid gland. Lab. Invest. 14: 310-320, 1965.

9) Hübner, G., Paulussen, F. and Kleinsasser, O.: Zur Feinstruktur und Genese der Onkocyten. Virchows Arch. Pathol. Anat. 343 : 34-50, 1967.

10) Tandler, B., Hutter, R. V. P. and Erlandson, R. A.: Ultrastructure of oncocytoma of the parotid gland. Lab. Invest. 23: 567-580, 1970.
11) Tandler, B.: Fine structure of oncocytes in human salivary glands. Virchows Arch. Pathol. Anat. 341: 317-326, 1966.

12) Crandall, R. B., Cebra, J. J. and Crandall, C. A.: The relative proportions of IgG-, IgA- and IgM-containing cells in rabbit tissues during experimental trichinosis. Immunology 12: 147-158, 1967.

13) Simons, K., Weber, T., Stiel, M. and Gräsbeck, R.: Immunoelectrophoresis of human saliva. Acta Med. Scand. 412: 257-264, 1964.

14) Korsrud, F. R. and Brandzaeg, P.: Characterization of epithelial elements in human major salivary glands by functional markers. J. Histochem. Cytochem. 30: 657-666, 1982.

15) Caselitz, J., Seifert, G. and Jaup, T.: Presence of carcinoembryonic antigen (CEA) in the normal and inflammed parotid gland. J. Cancer Res. Clin. Oncol. 100: 205-211, 1981c.

16) Caselitz, J., Jaup, T. and Seifert, G.: Immunocytochemische Darstellung von carcinoembryonalem Antigen in Parotiscarcinomen. Verhandl. Dtsch. Ges. Pathol. 64: 600, 1980. 